FOLIA HISTORICA CRACOVIENSIA, 20: 2014, s. 35-63

DOI: http://dx.doi.org/10.15633/fhc.649

Tomasz Gałuszka OP

DOMINIKAŃsKi InSTYTUT HistoRyCZNY

Uniwersytet Papieski Jana Pawea II w Krakowie

\title{
Studium generalne dominikanów polskich w XIV wieku?
}

\section{I}

W 2010 roku polscy dominikanie świętowali 6oo-lecie założenia dominikańskiego studium generalnego w Krakowie. Jednym $\mathrm{z}$ owoców tych obchodów był specjalny tom „Przeglądu Tomistycznego”, zawierający serię artykułów dotyczących szkolnictwa dominikanów w średniowieczu i epoce nowożytnej'. Głos zabrał m.in. uznany badacz historii polskiej prowincji dominikanów prof. Krzysztof Kaczmarek, który w konkluzji swojego studium stwierdził: „nie warto już wracać do teorii lokujących powstanie krakowskiego studium generale w wieku XIV, niezależnie od tego, czy do jego erygowania miałoby dojść na początku tego wieku, w połowie stulecia, czy też pod sam jego koniec" ${ }^{2}$. Rzeczywiście, w wyniku wieloletnich i skomplikowanych badań udało się ustalić, że pierwsze źródłowe dowody potwierdzające funkcjonowanie krakowskiego

1 „Przegląd Tomistyczny” T. 16: 2010; artykuły dotyczące problematyki szkolnictwa dominikańskiego w średniowieczu: K. Kaczmarek, Wokót historiograficznych sporów o początki dominikańskiego studium generalnego w Krakowie, s. 13-24; T. Gałuszka, W przededniu powstania „studium generale". Nowe badania nad czternastowiecznym zachowanym księozbiorem dominikanów krakowskich, s. 25-42; J. Turek, Regens krakowski Jan z soboru pizańskiego w świetle dwóch traktatów Jana Falkenberga, s. 43-57; A. Zajchowska, Czy w dominikańskim „studium generale” w Krakowie urządzano otrzęsiny? "Collatio de beanis” w rękopisie LXV6 z Archiwum Polskiej Prowincji Dominikanów w Krakowie, s. 59-75; M. Zdanek, Regensi dominikańskiego studium generalnego w Krakowie do 1596 r., s. 77-124.

${ }^{2}$ K. Kaczmarek, Wokół historiograficznych sporów..., s. 22-23. 
studium generale pochodzą z lat 1404/1405-14103. Należy jednak podkreślić, że przytoczone daty stanowią jedynie terminus ante quem powstania tego ośrodka kształcenia. W konsekwencji obserwacje i hipotezy sformułowane kilkadziesiąt lat temu przez Jerzego B. Korolca ${ }^{4}$, Roberta Świętochowskiego OP ${ }^{5}$ oraz Pawła Kielara $\mathrm{OP}^{6}$ na temat XIV-wiecznej metryki dominikańskiego studium nadal wymagają uwzględnienia i weryfikacji.

W niniejszej publikacji skupię się na pewnym wydarzeniu $\mathrm{z}$ lat 1304-1316, które w literaturze przedmiotu nazywane jest zazwyczaj „nieudaną próbą utworzenia studium generalnego w Krakowie". Zagadnienie to nie tylko nie doczekało się osobnego omówienia, ale uznane zostało za mało ważny incydent w historii polskich dominikanów. Co więcej, pojawiły się jego powierzchowne, a nawet błędne interpretacje, które z kolei nie pozostały bez wpływu na badania nad początkami dominikańskiego szkolnictwa wyższego.

\section{II}

Po 20 latach od założenia Ordo Fratrum Praedicatorum dominikanie postanowili przeprowadzić pierwszą poważną reformę, która miała objąć wszystkie aspekty ich życia. Inicjatorem tych zmian był trzeci generał zakonu Rajmund z Peñaford7. Od 1239 roku kolejne kapituły generalne przyjęły poprawioną wersję Księgi Konstytucji, w której znalazł się również obszerny rozdział De

${ }^{3}$ Zob. szczególnie tenże, Szkoły i studia polskich dominikanów w okresie średniowiecza. Poznań 2005, s. 330-345 (do tego rec. M. Zdanka, „Roczniki Historyczne” T. 72: 2006, s. 165-171); M. Zdanek, Szkoły i studia dominikanów krakowskich $w$ średniowieczu. Warszawa 2005, s. 82-98 (do tego rec. K. Kaczmarka, „Studia Źródłoznawcze” T. 45: 2007, s. 107-112).

${ }^{4}$ Zob. J. K. Korolec, Studium Generalne w Krakowie - prawne warunki istnienia. „Materiały i Studia Zakładu Historii Filozofii Starożytnej i Średniowiecznej” T. 4: 1965, s. 101-126; tenże, Studium generale dominikanów klasztoru Świętej Trójcy w Krakowie. W: Dominikanie w środkowej Europie w XIII-XV wieku. Pod red. J. Kłoczowskiego, J. A. Spieża. Poznań 2002, s. 181-182.

${ }_{5}$ Zob. R. Świętochowski, Szkolnictwo teologiczne dominikanów. W: Dzieje teologii katolickiej $w$ Polsce. T. 2, cz. 2. Pod red. M. Rechowicza. Lublin 1978, s. 236-237.

${ }^{6}$ Zob. P. Kielar, Studia nad kultura szkolna i intelektualna dominikanów prowincji polskiej $w$ średniowieczu. W: Studia nad historią dominikanów w Polsce. Pod red. J. Kłoczowskiego. T. 1. Warszawa 1975, s. 357-373, 456-515.

7 Zob. Magister Raimundus. Atti del convegno per il IV centenario della canonizzazione di San Raimondo de Penyafort: 1601-2001. Pod red. C. Longo. Roma 2002 (tam obszerna bibliografia). 


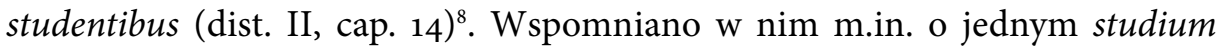
generale w Paryżu oraz zalecono, by każda prowincja wysyłała (mittantur) tam co roku trzech studentów ${ }^{9}$. Jednakże zapotrzebowanie na wykształconą kadrę nauczycielską było na tyle duże, że już kilka lat później władze zakonu postanowiły utworzyć nowe studia generalne. W 1246 roku w trakcie kapituły generalnej w Paryżu oficjalnie został zgłoszony projekt (inchoatio) powołania tego typu szkół w prowincji prowansalskiej, lombardzkiej, niemieckiej i angielskiej; miały one powstać przy klasztorach, w których działały już ośrodki kształcenia zakonnego - w Montpellier, Bolonii, Kolonii i Oksfordzie; każdy prowincjał otrzymał również prawo wysyłania tam (potestatem habeat mittendi) dwóch braci ${ }^{10}$. Zapis ten został potwierdzony (confirmatio) i wpisany do Księgi Konstytucji na kapitule generalnej w Paryżu w 1248 roku ${ }^{11}$.

W tym miejscu warto zwrócić uwagę na istotne rozróżnienie dotyczące wyznaczania braci do szkół generalnych. W przypadku studium generalnego przy paryskim konwencie Saint Jacques, nazywanego w aktach generalnych po prostu studium, każda prowincja miała obowiązek wysłania odpowiedniej liczby studentów. W czasie schizmy zachodniej i podziału zakonu rolę Paryża dla braci z obediencji rzymskiej przejęło studium generalne w Bolonii ${ }^{12}$. Przykładem tego typu sytuacji jest zarządzenie, jakie można odnaleźć w aktach polskiej kapituły prowincjalnej z 1384 roku: „Studio Bononiensi loco Parisius assignamus fratrem Rudolphum et fratrem Paulum"13. Co się zaś tyczy pozostałych szkół general-

${ }^{8}$ Zob. R. Creytens, Les constitutions des frères prêcheurs dans la redaction de s. Raymond de Peñafort (1241). „Archivum Fratrum Praedicatorum” T. 18: 1948, s. 65-67.

9 Zob. tamże, s. 66: „Curet prior provincialis ut si habuerit utiles aliquos ad docendum qui possunt in brevi apti esse ad regendum, mittere ad studendum ad loca ubi viget studium, et in aliis illi ad quos mittuntur eos non audeant occupare, nec ad provinciam suam remittere nisi fuerint revocati. Tres fratres mittantur Parisius tantum ad studium de provincia”.

${ }^{10}$ Zob. Acta capitulorum generalium ordinis Praedicatorum. Ed. B. M. Reichert. Romae-Stuttgardiae 1898-1899, Monumenta Ordinis Fratrum Praedicatorum historica. T. 1-8 (dalej: MOPH), tu T. 3, s. 34-35: „In constitucione ubi dicitur «Tres fratres mittantur Parisius tantum de provincia ad studium», addatur «quattuor autem provincie scilicet Provincia, Lombardia, Theotonia, Anglia provideant ut semper in aliquo conventu magis ydoneo sit generale studium et sollempne, et ad illum locum quilibet prior provincialis potestatem habeat mittendi duos fratres ad studium»".

${ }^{11}$ Zob. tamże, s. 38, 41.

${ }^{12}$ Zob. tamże, T. 8, s. 94-95.

${ }^{13}$ Zob. T. Gałuszka, Fragmenty czternastowiecznych akt kapituł prowincjalnych dominikanów polskich $w$ zbiorach Bayerische Staatsbibliothek $w$ Monachium. Kapituła prowincjalna w Opatowcu w 1384 r. „Studia Źródłoznawcze” T. 51: 2013, s. 121. 
nych, prowincjałowie otrzymali potestatem mittendi, co oznaczało, że mogli zgodnie $\mathrm{z}$ własnym uznaniem i potrzebami prowincji asygnować ratione studii jeszcze innych braci do ogólnozakonnych ośrodków kształcenia. Był to zatem specjalny przywilej asygnowania braci do klasztorów-studiów generalnych leżących na terenach innych prowincji. Teoretycznie więc każdy prowincjał mógł co roku wysyłać na studia zagraniczne od 3 do nawet 11 braci. Krzysztof Kaczmarek po przeanalizowaniu rzymskich akt kapituł prowincjalnych z pierwszej połowy XIV wieku wprost zauważył, że „widać wielką rolę Studium w paryskim konwencie św. Jakuba [...] znamy tylko 1 ustawę prowincji, w której nie ma asygnacji studentów do tego ośrodka; wszystkie pozostałe natomiast posyłały tam scholarów, i to zwykle w przepisanej przez kapituły generalne liczbie 3 osób" ${ }^{14}$. Ponadto zaobserwował on, że „władze prowincji rzymskiej asygnowały zakonników wyłącznie do kilku takich ośrodków, najczęściej położonych w Italii oraz Francji"15. Ów drugi wniosek, zdaniem tego badacza, miał dowodzić trudności $\mathrm{w}$ realizacji wszystkich postanowień kapituł generalnych. Przypuszczenie to zostało oparte na popularnym w literaturze przedmiotu, ale błędnym poglądzie, jakoby każda dominikańska prowincja była zobligowana do wysyłania swoich studentów do wszystkich zakonnych szkół wyższych. Obowiązek ten - raz jeszcze podkreślę - dotyczył wyłącznie studium generalnego w Paryżu ${ }^{16}$.

Przez kolejne ćwierć wieku dominikańskie szkolnictwo wyższe koncentrowało się wokół wspomnianych pięciu studiów generalnych. Dopiero w 1270 roku na kapitule w Mediolanie pojawiła się propozycja, by listę studiów generalnych uzupełnić o dwa nowe ośrodki - w prowincji hiszpańskiej i rzymskiej ${ }^{17}$. Zanim jednak doszło do urzeczywistnienia tego projektu, musiało minąć ponad dwadzieścia lat. Najpierw kapituła w 1271 roku nie podjęła tego tematu i powrócono do niego na kapitułach w latach 1272-1273 ${ }^{18}$. Jednak już zgromadzenie braci w Lyonie w 1274 roku ponownie zawiesiło prace nad tą reformą. Identyczna sytuacja miała miejsce

${ }_{14}$ Zob. K. Kaczmarek, Szkoly i studia..., s. 322.

${ }^{15}$ Tamże.

${ }^{16}$ Zob. np. zarządzenie kapituły generalnej w Magdeburgu z 1363 roku (MOPH, T. 4, s. 399): „Denunciamus provinciis ordinis universis, quod intendimus, quod studentes mittantur Parisius pro studio more solito". Warto zauważyć, że powyższy tekst według W. A. Hinnebuscha miał potwierdzać tezę o obowiązku wysyłania braci do wszystkich studiów generalnych, zob. W. A. Hinnebusch, The history of the Dominican Order. T. 2. New York 1973, s. 45.

${ }_{17}$ Zob. tamże, s. 153.

${ }^{18}$ Zob. tamże, s. 164, 167. W 1272 roku prowincja rzymska podjęła decyzję o zorganizowaniu studium generalnego w Neapolu i w tym celu wysłała tam Tomasza z Akwinu, zob. Acta 
w latach 1280 i 1283-1285 ${ }^{19}$. Co ciekawe, w 1282 roku kapituła w Wiedniu zgłosiła oryginalną propozycję, by każda prowincja zakonu z wyjątkiem jednostek misyjnych, to jest Grecji i Ziemi Świętej, założyła własne studia generalne ${ }^{20}$. Ewidentnie jednak inicjatywa ta była przedwczesna. Sprzyjające warunki do poszerzenia listy dominikańskich studiów generalnych zaistniały w latach 1288-1293. W pierwszej kolejności kapituły zajęły się problemem studium generalnego w prowincji rzymskiej i w 1290 roku uchwaliły otwarcie szkoły wyższej w Neapolu². Po podziale tej prowincji w 1294 roku studium generalne przeniesiono do Florencji, w Neapolu wznowiono kształcenie wyższe kilka lat później - w 1303 roku ${ }^{22}$. W latach 1291-1293 zajęto się reformą szkolnictwa w prowincji hiszpańskiej i oficjalnie wyrażono zgodę na założenie studium w Barcelonie ${ }^{23}$.

Prawdziwy przełom w dominikańskim szkolnictwie wyższym nastąpił w burzliwych dla zakonu latach 1298-1304, kiedy to bracia aż trzykrotnie wybierali nowych generałów. W 1298 roku kapituła generalna w Metzu pod przewodnictwem generała zakonu i przyszłego papieża Benedykta XI - Mikołaja Boccasiniego ${ }^{24}$ przedstawiła projekt (inchoatio) podziału pięciu prowincji zakonu: polskiej, hiszpańskiej, prowansalskiej, lombardzkiej i niemieckiej25. Głównym powodem tych zmian było dążenie do usprawnienia działalności całego zakonu, składającego się wówczas z 13 prowincji, 597 klasztorów męskich i 144 klasztorów żeńskich ${ }^{26}$. Ostatecznie w 1301 roku kapituła generalna w Kolonii podjęła decyzję o utworzeniu pięciu nowych prowincji: czeskiej, aragońskiej, tuluskiej, saksońskiej i - w ramach dawnej prowincji lombardz-

capitulorum Provincialium Provincioe Romanioe (1243-1344). Ed. T. Kæppeli. Romæ 1941, s. 39; J. P. Torrell, Tomasz z Akwinu - człowiek i dzieło. Warszawa 2008, s. 291-193.

19 Zob. MOPH, T. 3, s. 208, 223, 227.

${ }^{20}$ Zob. tamże, s. 217: „Item hanc. In capitulo De studentibus ubi dicitur «iiiior autem provincie scilicet. Provincia, Lombardia, Theotonia, Anglia» deleatur totum usque ibi "provideant» et dicatur sic «singule autem provincie, exceptis duabus scilicet Grecie et Terre sancte, provideant» etc.".

${ }^{21}$ Zob. tamże, s. 244, 248, 254.

${ }^{22}$ Zob. tamże, s. 325; W. A. Hinnebusch, The History..., s. 39; M. M. Mulchahey, „First the bow is bent in study". Dominican education before 1350. Toronto 1998, s. 384-390.

${ }_{23}$ Zob. MOPH, T. 3, s. 261, 265, 268.

${ }^{24}$ Zob. V. Sibilio, Benedetto XI. Il papa tra Roma e Avignone. Roma 2004.

${ }^{25} \mathrm{MOPH}$, T. 3, s. 287.

${ }^{26}$ Zob. D. A. Mortier, Histoire des Maitres Généraux. T. 2. Paris 1905, s. 331-332, 382-383; K. Kaczmarek, Podział polskiej prowincji dominikanów na przełomie XIII i XIV w. W: Kościót w monarchiach Przemyslidów i Piastów. Poznań 2009, s. 259-274. Materiały z konferencji naukowej Gniezno 21-24 września 2006 roku. Pod red. J. Dobosza. 
kiej - górnej (superioris) i dolnej (inferioris) Lombardiii ${ }^{27}$. Wraz z powstaniem nowych prowincji władze $\mathrm{w}$ pierwszej kolejności uregulowały sprawę liczby studentów wysyłanych do paryskiego studium generalnego. Już w 1301 roku prowincje polska, hiszpańska oraz czeska i aragońska zostały zobligowane do asygnowania po dwóch studentów ${ }^{28}$. Dwa lata później prawo to objęło również prowincje tuluską, prowansalską, Lombardii górnej, Lombardii dolnej i Saksonii ${ }^{29}$. W latach 1301-1303 ustalono również, że potestas mittendi prowincjałów wymienionych wyżej prowincji będzie dotyczyć tylko jednego brata $^{30}$. Zmniejszenie tych zobowiązań było podyktowane przede wszystkim dwoma racjami. Po pierwsze przepis ten dotyczył nowych jednostek zakonu, które - znacząco zmniejszone i osłabione - niewątpliwie potrzebowały czasu na przebudowanie struktur szkolnych i przystosowanie ich do nowych granic ${ }^{31}$. Przypomnę tylko, że polska prowincja została uszczuplona o 22 konwenty (38 proc.), prowincja hiszpańska o 19 konwentów (39 proc.), prowincja prowansalska o 25 konwentów (47 proc.), a prowincja niemiecka aż o 51 konwentów $(51 \text { proc. })^{32}$. Drugim powodem, dotychczas nieuwzględnianym $\mathrm{w}$ badaniach nad szkolnictwem dominikańskim, było dostosowanie studium paryskiego do napływu braci $z$ nowych prowincji. Pomimo wprowadzonego limitu liczba studentów zagranicznych, przynajmniej teoretycznie, zwiększała się z 33 do 38 braci. Biorąc natomiast pod uwagę XIII- i XIV-wieczne kontrowersje, a nawet konflikty, wokół obecności na studiach generalnych „obcych braci”, niewątpliwie władze zakonu musiały uwzględnić możliwości i interesy konwentu św. Jakuba, ale także innych studiów generalnych. Do zagadnienia fratres extranei powrócę nieco dalej. Dodać trzeba, że Krzysztof Kaczmarek w jednej ze swoich publikacji zaproponował inne wyjaśnienie wprowadzenia wspomnianych limitów ${ }^{33}$. Zwrócił on uwagę, że kapituły generalne w latach 1296-1297 zagroziły wprowadzeniem specjalnej sankcji wobec tych prowincji, które zbyt opieszale realizowałyby projekt organizacji nowych struktur - karą miało być usunięcie ze studiów generalnych w Paryżu i innych ośrodków po jednym

${ }_{27} \mathrm{MOPH}, \mathrm{T} .3$, s. 301, 303-304.

${ }_{28}$ Tamże, s. 288, 296, 301-302.

29 Tamże, s. 303-305, 312-314, 318-319.

3o Tamże, s. 288, 296, 302-304, 312-313, 318-319.

${ }^{31}$ Zob. K. Kaczmarek, Szkoły i studia..., s. 219, 309; M. Zdanek, Szkoły i studia..., s. 74.

${ }^{32}$ Wykaz według listy sporządzonej przez Bernarda Gui w latach 1303-1310, zob. D. A. Mortier, Histoire..., s. 382-383.

${ }_{33}$ Zob. K. Kaczmarek, Podziały..., s. 272. 
studencie ${ }^{34}$. Kaczmarek wysunął więc hipotezę, że „kiedy w roku 1298 kapituła po raz pierwszy określiła prowincji polskiej i czeskiej limity zakonników [...] to z premedytacją wyznaczyła je na niższym od innych prowincji poziomie, traktując (być może) takie rozwiązanie jako rodzaj kary za wcześniejsze kłótnie o to, czy i jak się podzielić" ${ }^{35}$. Powyższa propozycja budzi jednak pewne wątpliwości. Rzeczywiście, kapituły z roku 1296 i 1297 zgłosiły ten rodzaj surowej sankcji, ale był to jedynie projekt, który nie został podjęty przez zgromadzenie w 1298 roku. Ponadto, przyjmując interpretację tego badacza, należałoby uznać, że karę tę nałożono nie tylko na prowincję polską i czeską, ale również na - wymienione w uchwale z tego roku - hiszpańską, aragońską oraz jednostki misyjne, a w dalszych latach także na kolejne 5 prowincji. Trudno jest sobie wyobrazić ogłoszenie jakiejkolwiek uchwały, która karałaby w sposób trwały połowę całego zakonu.

Reforma administracji była pierwszym krokiem do realizacji szerszego programu odnowy życia zakonnego. Jedną z kluczowych kwestii był rozwój szkolnictwa wyższego i przygotowanie wykwalifikowanej kadry nauczycielskiej. Już $\mathrm{w} 1302$ roku kapituła generalna w Bolonii powróciła do pomysłu sprzed 20 lat $^{36}$ i przedstawiła wstępny projekt zmian w tekście Księgi Konstytucji, w rozdziale De studentibus: „In capitulo De studentibus, ubi dicitur «sex autem provincie» etc. deleatur [sex] et ponatur «quelibet autem provincia, exceptis Dacie, Grecie, Terre sancte, provideat, ut semper in aliquo conventu ydoneo sit generale studium et solempne»" ${ }^{37}$. Autorem i głównym promotorem tego zapisu był nowy generał zakonu i emerytowany wykładowca studium generalnego w Montpellier - Bernard de Jusix ${ }^{38}$. Wspomnieć warto, że w trakcie jego krótkiej kadencji kapituły zajęły się jeszcze jednym ważnym zagadnieniem ściśle powiązanym z kulturą intelektualną dominikanów - udzielono mistrzom teologii stałej dyspensy od zachowania milczenia w refektarzu i w innych miejscach klasztoru ${ }^{39}$. Daniel-Antoine Mortier określił ten przywilej jako „témoignage d'honneur et de gratitude a ceux dont la science eminente illustrait les maisons de l'Order" ${ }^{40}$. Zmiany w rozdziale De studentibus zostały zainicjowane (inchoatio)

\footnotetext{
${ }^{34}$ Zob. MOPH, T. 3, s. 278, 282-283.

${ }^{35}$ Zob. K. Kaczmarek, Podziały..., s. 272.

${ }^{36}$ Zob. przyp. 20.

${ }_{37} \mathrm{MOPH}, \mathrm{T} .3$, s. 314.

${ }^{38}$ Zob. D. A. Mortier, Historie..., s. 375-420.

${ }^{39} \mathrm{MOPH}$, T. 3, s. 320; T. 4, s. 3,8 .

${ }^{40}$ D. A. Mortier, Historie ..., s. 387.
} 
i zaaprobowane (approbatio) na dwóch kolejnych kapitułach generalnych definitorów, tzn. przedstawicieli lokalnych wspólnot, wybranych na kapitułach prowincjalnych ${ }^{41}$. Ponieważ projekt ten wprowadzili i akceptowali definitorzy, można domniemywać, że miał on pełne poparcie nie tylko najwyższych władz zakonu i prowincji, ale również „szeregowych braci”. Było to o tyle ważne, że otwarcie studium generalnego oprócz niewątpliwych korzyści intelektualnych i prestiżowych wiązało się z poważnymi nakładami finansowymi, dotykającymi całą prowincję. Definitywną decyzję podjęła kapituła generalna prowincjałów w Tuluzie w 1304 roku $^{42}$; kapitule przewodził nowy generał zakonu Aymeric de Plaisance, nazywany "generałem studentów” ${ }^{43}$. Zarządzenie to zostało włączone do Księgi Konstytucji i bezpośrednio dotyczyło 15 prowincji zakonu. Z tego obowiązku zostały zwolnione trzy prowincje: Dacji, Grecji i Ziemi Świętej. Wykluczenie dwóch ostatnich było w pełni uzasadnione - prowincja jerozolimska liczyła tylko 3 położone na Cyprze klasztory, a prowincja grecka obejmowała 9 klasztorów, będących stacjami misyjnymi dla mendykantów skupionych w Kongregacji Braci Pielgrzymujących dla Chrystusa (Societas fratrum peregrinantium propter Christum inter gentes) ${ }^{44}$. Dołączenie do tej listy prowincji Dacji wymaga nieco szerszego komentarza.

Na początku XIV wieku prowincja Dacji liczyła 27 klasztorów, ufundowanych na terenie Danii (15 konwentów), Szwecji (9 konwentów) i Norwegii (3 konwentów) ${ }^{45}$. Była ona większa od prowincji aragońskiej (19 klasztorów), sycylijskiej (20 klasztorów), czeskiej (22 klasztory) i tuluskiej (25 klasztorów). W XIII wieku prowincja Dacji posiadała rozbudowaną sieć szkół konwentualnych i partykularnych ${ }^{46}$. $\mathrm{Z}$ tych też zapewne powodów została uwzględniona we

${ }^{41}$ Według średniowiecznego prawodawstwa dominikańskiego kapituły generalne powinny były odbywać się co roku w następującym porządku: dwie kapituły generalne definitorów, po których była jedna kapituła prowincjałów. Zob. G. R. Galbraith, The constitution of the Dominican order 1216 to 1360 . Manchester 1925, s. 85-109.

${ }^{42} \mathrm{MOPH}, \mathrm{T} .4$, s. 1.

${ }_{43}$ D. A. Mortier, Historie..., s. 422-494, szczególnie s. 437-442.

${ }_{44}$ Zob. R. Loenertz, La Société des Fréres Pérégrinants. Roma 1937; C. Delacroix-Besnier, Les Dominicains et la chrétienté grecque aux XIV et XV siècles. Rome 1997.

${ }^{45}$ Zob. E. F. Rosenorn Lehn, La province de Dacia (Danemark, Suède et Norvèqe). Rome 1899, s. 277; J. Gallén, La province de Dacie de l'Order des Frères Prêcheurs. Helsingfors 1946; A. T. Hommedal, The Medieval Dominican Friary of St Olav in Oslo, Norway. History and Architecture. W: Dominikanie. Gdańsk - Polska - Europa. Pod red. D. A. Dekańskiego, A. Golembnika, M. Grubki. Gdańsk-Pelplin 2003, s. 371-388.

${ }^{46}$ Zob. E. F. Rosenorn Lehn, La province..., s. 10. 
wspominanym już kilkukrotnie pierwszym projekcie rozwoju szkolnictwa wyższego $\mathrm{z} 1282$ roku. Zdaniem Edle F. Rosenorn Lehn, monografistki prowincji Dacji, „C' est aux $13^{\text {me }}$ et $14^{\text {me }}$ siècle que l'Ordre florissait en Dacia, et que son influence était considérable dans toutes les sphères"47. Być może rzeczywiście dominikanie z północy Europy cieszyli się uznaniem w lokalnym Kościele i społeczeństwie, jednak w ocenie władz zakonu, zwłaszcza na przełomie XIII i XIV wieku, ich sposób życia wewnątrz prowincji pozostawiał wiele do życzenia. Warto pamiętać, że Dacja, wraz z prowincją polską, grecką i Ziemi Świętej, do 1241 roku należała do grupy tzw. prowincji mniejszych. Oznaczało to, że mogła ona korzystać tylko z części praw zakonnych, np. miała tylko jeden głos $w$ wyborach generała zakonu ${ }^{48}$. I choć owa "nierówność” została szybko usunięta, to wśród „prowincji większych” pamięć o niegdysiejszej przynależności do rzeczonej grupy była nadal żywa. W 1291 roku kapituła generalna $\mathrm{w}$ jednym $\mathrm{z}$ zarządzeń wyznaczyła dwóch wizytatorów, którzy mieli zbadać sytuację w prowincji Dacji oraz nakazała, by generał wysłał podobnych wizytatorów do prowincji Grecji i Ziemi Świętej ${ }^{49}$. Ponadto podczas tego właśnie zgromadzenia $\mathrm{z}$ nieznanych obecnie powodów został usunięty z urzędu prowincjał Dacji - Olaf z Roskilde ${ }^{50}$. Dominikanin ów, wybrany ponownie na miejscowego prowincjała, sprawował tę funkcję aż do kapituły generalnej w Bolonii $\mathrm{w} 1302$ roku, kiedy to został definitywnie pozbawiony urzędu. W trakcie jego prowincjalatu miał miejsce pewien incydent, którym zajęła się kapituła generalna w 1300 roku. W czasie gdy prowincjał Olaf przebywał poza granicami prowincji, brat Gotfryd, lektor z klasztoru w Stralsund, niezadowolony z przydzielonej mu celi lektorskiej zajął pokój prowincjała i zbuntował się przeciwko władzom klasztornym ${ }^{51}$. Kapituła generalna nałożyła nań odpowiednią sankcję - przez rok nie mógł nauczać i asygnowała go do innego klasztoru. W kolejnych latach dał się zaobserwować wzrost niepokojów wewnątrz prowincji Dacji. W 1304 roku, a więc w momencie gdy władze zakonu wprowadzały omawiane tu zmiany w rozdziale De studentibus, kapituła generalna zdjęła $\mathrm{z}$ urzędu wszystkich definitorów zasiadających $\mathrm{w}$ radzie prowincji Dacji. Oskarżenie było poważne - w trakcie kapituły prowincjalnej

\footnotetext{
47 Tamże, s. 19.

${ }_{48}$ MOPH, T. 3, s. 11, 14, 18.

49 Tamże, s. 263.

50 Zob. J. Gallén, La province..., s. 62-64.

${ }^{51}$ Tamże, s. 63; MOPH, T. 3, s. 309.
} 
wspólnie z prowincjałem Piotrem z Roskilde pozbawili miejscowych kaznodziejów generalnych ich tytułów ${ }^{52}$. Wreszcie $\mathrm{w} 1308$ roku również prowincjał Piotr został dyscyplinarnie usunięty $\mathrm{z}$ piastowanego urzędu ${ }^{53}$. Wspomniane wyżej wydarzenia pozwalają przypuszczać, że na początku XIV wieku sytuacja w prowincji Dacji odbiegała od normy. W konsekwencji jest zatem wysoce prawdopodobne, że władze zakonu, podejmując decyzję o wykluczeniu tej prowincji z planów zakładania studiów generalnych, wzięły pod uwagę przede wszystkim wewnętrzne konflikty - które ewidentnie nie sprzyjały podejmowaniu ambitnych projektów - oraz trudności we współpracy z przełożonymi tej prowincji. Oczywiście otwarte pozostanie pytanie, czy bracia z tej części zakonu w ogóle chcieli zaangażować się w zakładanie szkoły wyższej? Przypadek prowincji Dacji pokazuje, że kapituły generalne z lat 1302-1304, inicjując plan założenia studiów wyższych w 15 prowincjach, uwzględniały nie tylko możliwości kadrowe i materialne, ale również bieżącą sytuację wewnątrz tych jednostek zakonu. Okazuje się, że wielkość prowincji, obecność rozwiniętej organizacji szkolnej oraz stosownej grupy wykładowców nie dawały wystarczających podstaw do założenia studium generalnego. W tym kontekście trudno zgodzić się $\mathrm{z}$ opinią wyrażoną m.in. przez Pawła Kielara, że ustawy reorganizujące system szkolnictwa dominikańskiego wydane na kapitułach z początku XIV stulecia miały wyłącznie charakter postulatywny ${ }^{54}$.

Niewątpliwie decyzja kapituły w Tuluzie otworzyła nowy etap w dziejach szkolnictwa dominikańskiego. Przez kolejne kilkadziesiąt lat - o czym dalej będzie mowa - liczba studiów generalnych w stosunku do XIII wieku wzrosła $\mathrm{z} 7$ do ponad 20. Jednak wypracowanie w 1304 roku podstaw prawnych było pierwszym i niezbędnym krokiem $\mathrm{w}$ realizacji tego przedsięwzięcia. W przypadku trzech prowincji: polskiej, węgierskiej i czeskiej zadanie to było tym trudniejsze, że na ich terenie nie było wcześniej żadnej szkoły wyższej i uniwersyteckich wydziałów teologii, a najbliższe dominikańskie studia generalne znajdowały się w Kolonii i Bolonii. Już w 1305 roku kapituła generalna w Genewie ogłosiła, że „ad studia generalia assignata provinciis Ungarie, Polonie, Boemie studens aliquis extraneus non mittatur, donec per magistrum ordinis

\footnotetext{
${ }_{52}$ Zob. J. Gallén, La province..., s. 65; MOPH, T. 4, s. 26.

${ }^{53} \mathrm{MOPH}, \mathrm{T} .4$, s. 35.

${ }_{54}$ Zob. P. Kielar, Powstanie dominikańskiego studium..., s. 335-336; K. Kaczmarek, Głos w dyskusji nad początkami studium generalnego dominikanów w Krakowie. „Nasza Przeszłość” T. 91:
} 1999, s. 83 . 
et generale capitulum aliter fuerit ordinatum"55. Zapis został wprowadzony najprawdopodobniej na specjalną prośbę definitorów tych trzech prowincji, którzy przedstawili zgromadzeniu generalnemu relację z prac nad organizacją lokalnych studiów generalnych. W tekście zarządzenia pojawia tylko jeden nakaz - do węgierskich, polskich i czeskich studiów generalnych nie wolno aż do odwołania wysyłać studentów zagranicznych. Rodzi się jednak fundamentalne pytanie: czy ta ordinatio była świadectwem troski ze strony władz zakonu i konkretnym wsparciem w początkowych etapach organizacji tych studiów, czy też przeciwnie - wyrazem rozczarowania i swego rodzaju sankcją? W literaturze przedmiotu istnieją dwie dominujące interpretacje. Jerzy Kłoczowski uznał, że kapituła generalna w 1305 roku skorygowała swoje plany i w miejscu tych studiów generalnych utworzyła studia wyższe, działające wyłącznie na potrzeby prowincji; spadły one zatem do roli tzw. studium solennego $0^{56}$. Autorem drugiej interpretacji był Paweł Kielar, który twierdził, że polska prowincja (i de facto pozostałe dwie) nie były przygotowane na utworzenie szkoły wyższej $\mathrm{z}$ uwagi na niski poziom nauczania, słabo rozwiniętą sieć szkolnictwa oraz sytuację polityczną. Doszedł on do wniosku, że prowincjał polski poinformował władze zakonu, iż nie może jednak wykonać decyzji z 1304 roku o założeniu studium generalnego, a te $\mathrm{z}$ kolei zawiesiły wykonanie konstytucji „aż nastaną lepsze czasy"s7. Podkreślę od razu, że badacz ten pominął ważny fakt, iż kapituła generalna w 1305 nie była kapitułą prowincjałów, ale definitorów, a w tekście zarządzenia wymieniona jest nie tylko prowincja polska, lecz jeszcze dwie inne. Hipoteza Kielara zastała powszechnie przyjęta w historiografii i zamknęła dyskusję na temat wydarzeń z początku XIV wieku. Łatwo jednak zauważyć, że wyjaśnienia zaproponowane przez Kłoczowskiego, a zwłaszcza Kielara, skoncentrowały się wyłącznie na „pesymistycznej genezie” powstania zarządzenia z 1305 roku. Jeżeli zatem kapituła generalna zaledwie po roku miałaby wycofać się ze swoich planów i de facto stwierdzić, że przeprowadzona trzyletnia procedura była bezużyteczna, a ocena sytuacji wewnętrznej w tych trzech prowincjach błędna, dlaczego od razu nie zgłoszono nowego projektu

${ }_{55} \mathrm{MOPH}, \mathrm{T} .4$, s. 14.

${ }^{56}$ Zob. J. Kłoczowski, Dominikanie polscy na Śląsku w XIII-XIV wieku. Lublin 1956, s. 225-226. Dzięki badaniom M. M. Mulchaheya wiadomo, że w ustawodawstwie dominikańskim określenia studium generale i studium solenne są synonimami, zob. M. M. Mulchahey, First the bow..., s. 355, przyp. 11; M. Zdanek, Szkoly i studia..., s. 37, przyp. 8o.

${ }_{57}$ Zob. P. Kielar, Powstanie dominikańskiego studium..., s. 336. 
(inchoatio) dołączenia Polski, Węgier i Czech do Dani, Grecji i Ziemi Świętej, czyli grupy prowincji nieposiadających studium generalnego? Już choćby w świetle tej wątpliwości warto nieco dokładniej przyglądnąć się nakazowi, jaki znalazł się w omawianym zarządzeniu z 1305 roku.

Jedną z cech dominikańskich studiów generalnych była powszechna rekrutacja obejmująca braci ze wszystkich prowincji ${ }^{58}$. Prawo zakonne nie tylko dokładnie regulowało liczbę studentów, ale również nakładało na prowincje obowiązek ich utrzymania ${ }^{59}$. W pierwszych latach XIV wieku kapituły generalne zobowiązały prowincjałów, by raz w roku pokrywali koszty zakupu ubrań dla swoich studentów oraz opłat związanych z pobytem na studiach generalnych - w 1305 roku były to 2 floreny, a w 1315 roku już 4 floreny $^{60}$. Same ośrodki kształcenia również musiały ponosić część kosztów związanych z obecnością w ich murach wspólnoty studentów i wykładowców, m.in. troszczyły się o zakup i naprawę obuwia, a niekiedy także wyżywienie ${ }^{61}$. Już w 1289 roku doszło do finansowej zapaści studium paryskiego, które $\mathrm{z}$ powodu zalegania $\mathrm{z}$ opłatami przez studentów zagranicznych oraz ich zbyt dużej liczby podpadło w ogromne długi ${ }^{62}$. Podobnie również $\mathrm{w}$ drugiej połowie XIV wieku władze zakonu zwróciły uwagę na trudną sytuację materialną tej najważniejszej dominikańskiej uczelni ${ }^{63}$. Próbując zaradzić owym problemom, kapituła generalna w 1315 roku wydała serię zarządzeń: prowincjałowie mieli unikać wystawiania zbyt dużej liczby asygnat do klasztorów, które posiadały szkoły; mogło być jedynie 22-23 studentów tzw. wewnętrznych, czyli pochodzących z miejscowej prowincji; zakazano także kumulowania $\mathrm{w}$ jednym domu zakonnym szkół partykularnych sztuk i filozofii oraz studiów generalnych ${ }^{64}$. Ponadto absolwent studiów wyższych miał niezwłocznie powrócić do swojej prowincji, a w przypadku rodzimych braci - oczekiwać na asygnatę ${ }^{65}$. Problemy finansowe i wysokie koszty utrzymania szkół były główną, ale nie jedyną przyczyną niechęci studiów generalnych do przyjmowania studentów zagranicznych. W XIII- i XIV-wiecznych aktach

${ }^{8}$ Zob. M. M. Mulchahey, First the bow..., s. 372-378.

59 Zob. np. MOPH, T. 3, s. 9, 82, 100; T. 4, 18, 32, 41, 78, 246; W. A. Hinnebusch, The history..., s. 54-56; K. Kaczmarek, Szkoły i studia..., s. 319-320.

6o Zob. MOPH, T. 4, s. 3, 11, 82.

${ }^{61}$ Zob. tamże, s. 78-79, 399-40o.

${ }^{62}$ Zob. tamże, T. 3, s. 253.

${ }_{63}$ Zob. tamże, T. 4, s. 388, 399.

${ }^{64}$ Zob. tamże, s. 14.

${ }^{65}$ Zob. tamże, s. 175. 
kapituł generalnych występuje szereg przykładów ukazujących trudności w realizacji ogólnozakonnej misji szkół wyższych. W 1261 roku kapituła generalna przypomniała angielskim dominikanom, że studium w Oksfordzie jest studium pro provinciis i nałożyła surowe pokuty na tamtejszego prowincjała i jego zarząd za odmowę przyjmowania studentów z zewnątrz ${ }^{66}$. W 70. latach XIV wieku kwestia obecności studentów zagranicznych $\mathrm{w}$ drugim angielskim studium generalnym w Cambridge doprowadziła do otwartego konfliktu władz zakonu z władzami prowincji ${ }^{67}$. W 1373 roku król Ryszard II za namową angielskiego prowincjała Tomasza Russhocka (Vichor) nakazał usunięcie pod zarzutem szpiegostwa części zagranicznych studentów. Generał Eliasz z Tuluzy zareagował natychmiast i ustanowił swojego wikariusza, który miał przeprowadzić śledztwo i przywrócić ład w prowincji. Angielscy zakonnicy jednak nie tylko zignorowali decyzję generała, ale z pomocą władzy świeckiej uwięzili zarówno wikariusza generalskiego, jak i jego zwolenników. Ostatecznie w 1378 roku sprawą zajął się sam generał i kapituła w Carcassonne. Zdecydowano o usunięciu z urzędu dotychczasowego prowincjała Anglii i 12 przeorów oraz odebraniu kilku dominikańskim mistrzom i wykładowcom licencji nauczania; ponadto nieposłusznych zakonników obłożono odpowiednimi karami z ekskomuniką włącznie. Konflikt zakończył się dopiero w sierpniu 1379 roku po interwencji papieża Urbana VI - Tomasz powrócił na urząd prowincjała, a studenci zagraniczni mogli kontynuować naukę w Anglii. Podobne spory toczyły się także w innych dominikańskich studiach generalnych. W 1265 roku kapituła generalna wyznaczyła prowincjałowi niemieckiemu 12-dniowy post o chlebie i wodzie oraz usunęła go z piastowanego urzędu; powodem było odesłanie kilku studentów zagranicznych ${ }^{68}$. Jednak, jak przypuszcza Gabriel M. Löhr, prowincjał ten kierował się nie tyle niechęcią do studentów zagranicznych, ile przede wszystkim poważnymi problemami finansowymi i lokalowymi szkoły kolońskiej ${ }^{69}$. Z kolei wspomniane już trudności studium paryskiego z pewnością nie ułatwiały budowania dobrych

${ }^{66}$ Zob. tamże, T. 3, s. 110-111.

${ }^{67}$ Zob. MOPH, T. 4, s. 250-252; W. A. Hinnebusch, The History..., s. 50-53; A. B. Emden, Dominican confessors and preachers. „Archivum Fratrum Praedicatorum” T. 32: 1962, s. 184, 191; tenże, A survey of Dominicans in England based on the ordination lists in episcopal registers (1268 to 1538). Rome 1967, s. 439-440; T. Gałuszka, Fragment akt kapituły prowincjalnej dominikanów polskich $z$ 9o. lat XIV wieku. Studium historyczne i edycja tekstu. „Roczniki Historyczne” T. 79: 2013, s. 136.

${ }^{68}$ Zob. MOPH, T. 3, s. 131.

${ }^{69}$ Zob. G. M. Löhr, Die Kölner Dominikanerschule vom 14. bis zum 16. Jahrhundert mit einer Übersicht über die Gesamtentwicklung. Köln 1948, s. 13-14. 
relacji pomiędzy francuskimi dominikanami a studentami z innych prowincji. W 1287 roku kapituła generalna wysłała wizytatorów do Paryża, aby ukarali tych spośród studentów, którzy doprowadzili do niepokojów w konwencie św. Jakuba. Wizytatorzy otrzymali prawo dyscyplinarnego odesłania studentów zagranicznych oraz asygnowania miejscowych braci do innych konwentów ${ }^{\circ}$. Kończąc ten krótki przegląd, warto podkreślić, że przyjmowanie fratres extranei $\mathrm{w}$ dominikańskich studiach generalnych było raczej wypełnieniem w duchu posłuszeństwa nakazów władz zakonu niż pożądanym przez te ośrodki przywilejem. Każdy student generalny bowiem był poważnym obciążeniem dla budżetu klasztoru, a co więcej zajmował miejsce braciom - studentom $\mathrm{z}$ prowincji, na której terenie znajdowało się dane studium. Nie dziwi zatem niechęć i opór ze strony studiów generalnych przed zbytnim otwarciem na „obcych”.

Powyższe obserwacje pozwalają zatem nieco inaczej spojrzeć na zarządzenie kapituły z 1305 roku. Wbrew dotychczasowym interpretacjom nie było ono ani degradacją studiów generalnych w Polsce, Czechach i na Węgrzech, ani też rezygnacją z projektu rozbudowy szkolnictwa wyższego na tych terenach. Kapituła zgodnie z prawem zakonnym udzieliła tym trzem prowincjom swego rodzaju „dyspensy”, która miała na celu uchronienie ich zarówno przed dodatkowymi kosztami, jak i ewentualnymi konfliktami wewnątrz prowincji i w samym zakonie. W zamierzeniu kapituły objęte tym zarządzeniem trzy prowincje miały skupić się na spokojnym wypracowaniu solidnych podstaw materialnych i kadrowych, tak by w przyszłości mogły się otworzyć na studentów z zagranicy.

W kolejnych latach zakon zintensyfikował działania na rzecz rozwoju szkolnictwa dominikańskiego. W 1315 roku kapituła generalna zajęła się miejscem szkół prowincjalnych i generalnych w strukturach i życiu wewnętrznym klasztorów ${ }^{71}$, a rok później prowincjałowie zebrani w Montpellier przyjęli wstępny projekt zmian (inchoatio) w rozdziale De studentibus. W obszernej ustawie poruszono m.in. kwestię liczby studentów wysyłanych przez prowincjałów do studiów generalnych oraz - co szczególnie ważne z perspektywy niniejszego studium - przypomniano decyzję z 1304 roku o konieczności założenia w prowincjach zakonu studium generalnego, przy czym do listy prowincji zwolnionych z tego obowiązku dołączono Polskę, Czechy, Węgry oraz Hiszpanię ${ }^{72}$.

7o Zob. MOPH, T. 3, s. 241.

${ }^{71}$ Zob. przyp. 64.

${ }_{72} \mathrm{MOPH}$, T. 4, s. 59-60: „Cum pro eo, quod diverse provincie ad generalia studia, Parisiensi excepto, possint unum tantum fratrem mittere pro studente, multa incommoda et dispendia 
Nie są znane dokładne okoliczności i powody powstania tego projektu, można jednak przypuszczać, że był on reakcją zakonu na niezadowalający stopień organizacji studiów generalnych w tych czterech prowincjach. Była to swego rodzaju groźba, która miała na celu przypomnienie o aktualności konstytucji z 1304 roku. Należy zaznaczyć, że najprawdopodobniej na kapitułę w 1316 roku nie dotarła delegacja $\mathrm{z}$ Polski i zapis ten powstał bez wiedzy władz prowincji ${ }^{73}$. Wiadomo natomiast, że projekt musiał wywołać albo opór - jak przypuszcza Paweł Kielar ${ }^{74}$ - albo poprawę ze strony zainteresowanych prowincji, skoro następna kapituła w 1317 roku odrzuciła go i nadal utrzymała w mocy uchwaloną 13 lat wcześniej konstytucję. W latach 1323-1325 udało się uchwalić tylko jeden postulat zawarty w rzeczonym projekcie z 1316 roku - dotyczący liczby studentów wysyłanych na studia wyższe ${ }^{75}$. Kolejne kapituły generalne w XIV nie podejmowały już zagadnienia obecności lub braku studiów generalnych w prowincji polskiej, czeskiej, węgierskiej i hiszpańskiej. Czy oznacza to, że rzeczywiście w każdej z wyznaczonych prowincji powstały studia generalne?

Próbując odpowiedzieć na to pytanie, warto zrekonstruować listę wszystkich znanych studiów generalnych w zakonie dominikańskim w XIV wieku. Podstawą źródłową będą przede wszystkim wystawiane przez kapituły generalne imienne asygnaty do zakonnych ośrodków kształcenia ${ }^{76}$.

subsequantur, tum quia sic assignatis communiter opportuno tempore socius non occurrit, tum eciam quia studia posita sunt in remotis, fratres accedendo ad illa gravant seipsos et provincias in expensis, inchoamus hanc: in capitulo de studentibus, ubi dicitur «quelibet autem provincia» etc., dicatur sic «quelibet autem provincia, exceptis Ispanie, Ungarie, Terre sancte, Polonie, Dacie, Grecie et Boemie, provideat, ut semper in conventu aliquo ydoneo sit generale studium et sollempne, et ad illum locum quilibet prior provincialis de diffinitorum capituli provincialis vel maioris partis eorum consilio et assensu potestatem habeat mittendi duos fratres ydoneos ad studendum modo videlicet infrascripto, ut scilicet ad studia provinciarum Lombardie inferioris, Romane provincie, regni Sicilie, Theutonie, superioris Lom bardie tantum duos fratres mittere possint ipse nunc nominate provincie et cum eis provincie Ungarie, Grecie, Polonie et Dacie. Ad studia vero provinciarum Tholosane, Anglie, Aragonie, provincie Provincie et Saxonie mittere tantum possint similiter duos fratres, ipse nunc nominate provincie et cum eis provincie Hyspanie, Francie, Terre sancte et Boemie. Quelibet autem provincia divisa mittere possit quattor fratres ad studium provincie condivise»".

${ }^{73}$ Zob. T. Gałuszka, Liber constitutionum dominikanów krakowskich z lat 1273-1318. „Studia Źródłoznawcze" T. 50: 2012, s. 18.

${ }_{74}$ Zob. P. Kielar, Powstanie dominikańskiego studium..., s. 337.

${ }_{75}$ Zob. MOPH, T. 4, s. 143, 151, 156.

${ }^{76}$ Pierwsze tego rodzaju imienne asygnaty odnaleźć można w 2. poł. XIII wieku, lecz dotyczyły one jedynie studium paryskiego (Zob. MOPH, T. 3, s. 193, 242). W przypadku pozostałych ośrodków kapituły generalne aż do początku XIV wieku obowiązek ten powierzały bezpośrednio 
Tabela 1. Studia generalne dominikanów w XIII-XIV wieku

\begin{tabular}{|c|c|c|c|}
\hline Prowincja zakonu & $\begin{array}{l}\text { Miasto (studium } \\
\text { generale) }\end{array}$ & Rok założenia & $\begin{array}{l}\text { Asygnaty kapituł generalnych na studia } \\
\text { generalne w XIV wieku }\end{array}$ \\
\hline \multirow[t]{2}{*}{ angielska } & Oksford & 1248 & MOPH, T. 4, s. 417, 433, 447 \\
\hline & Cambridge & $1303-1313$ & MOPH, T. 4, s. 417, 433, 447 \\
\hline aragońska & Barcelona & post 1293 & MOPH, T. 4, s. $278,330,337,435,448$ \\
\hline czeska & Praga & ante 1347 & MOPH, T. 4, s. $319,325,330,448$ \\
\hline francuska & Paryż & 1220 & $\begin{array}{l}\text { MOPH, T. } 4 \text {, s. } 55,86,155,167,186,200 \text {, } \\
215,222,227,234,242,251,258,268, \\
278,283,291,305,311,325,330,337, \\
401,417,433,447\end{array}$ \\
\hline \multirow[t]{3}{*}{ hiszpańska } & Salamanka & ante 1304 & MOPH, T. 4, s. 251, 259, 330, 337 \\
\hline & Lizbona & ante 1339 & MOPH, T. 4, s. 259 \\
\hline & $\begin{array}{l}\text { Santiago de } \\
\text { Compostella }\end{array}$ & ante 1344 & MOPH, T. 4, s. 305 \\
\hline \multirow[t]{3}{*}{ dolnolombardzka } & Bolonia & 1248 & $\begin{array}{l}\text { MOPH, T. 4, s. } 86,283,215,234,251 \text {, } \\
278,291,167,305,311,319,325,330 \text {, } \\
401,417,434,448\end{array}$ \\
\hline & Wenecja & ante 1340 & MOPH, T. 4, s. $268,435,448$ (?) \\
\hline & Rimini (Padwa) & $\begin{array}{l}\text { post } 1350 \\
\text { (Padwa - 1397) }\end{array}$ & MOPH, T. 8, s. 98 \\
\hline \multirow[t]{2}{*}{ górnolombardzka } & Mediolan & ante 1339 & MOPH, T. 4, s. $337,435,449$ \\
\hline & Genua & ante 1307 & - \\
\hline niemiecka & Kolonia & post 1248 & $\begin{array}{l}\text { MOPH, T. 4, s. } 337,401,417,434,448 \\
\text { VIII, } 97\end{array}$ \\
\hline \multirow[t]{2}{*}{ prowansalska } & Montpellier & 1248 & $\begin{array}{l}\text { MOPH, T. } 4 \text {, s. } 278,283,305,319,401 \text {, } \\
417,435,448\end{array}$ \\
\hline & Awinion & ante 1342 & MOPH, T. 4, s. 283, 319, 330, 435, 448 \\
\hline rzymska & Florencja & 1294 & MOPH, T. 4, s. $283,417,449$ \\
\hline \multirow[t]{2}{*}{ saksońska } & Magdeburg & ante 1315 & MOPH, T. 4, s. 251, 283, 401, 448 \\
\hline & Erfurt & ante 1394 & - \\
\hline sycylijska & Neapol & 1303 & $\begin{array}{l}\text { MOPH, T. } 4 \text {, s. } 259,325,337,401,434 \text {, } \\
448\end{array}$ \\
\hline \multirow[t]{2}{*}{ tuluska } & Tuluza & post 1303 & $\begin{array}{l}\text { MOPH, T. } 4 \text {, s. } 172,234,242,259,268 \\
283,330,337,401,433,447\end{array}$ \\
\hline & Bordeaux & ante 1376 & MOPH, T. 4, s. 435,448 \\
\hline węgierska & Buda & ante 1350 & MOPH, T. 4, s. 337 \\
\hline
\end{tabular}

generałowi zakonu (Zob. MOPH, T. 3, s. 138, 142, 149, 155, 160, 182, 198, 204, 241, 247, 259, 264, 267, 271, 281, 286, 291, 298, 310, 317, 326; T. 4, s. 7, 14, 20, 27, 37, 44, 49). Od 1315 roku w aktach kapituł generalnych pojawiają się asygnaty także do studiów generalnych leżących w innych dominikańskich prowincjach. 
Z tabeli tej można wyciągnąć przynajmniej pięć następujących wniosków na temat dominikańskich studiów generalnych w XIV wieku. Po pierwsze, w zakonie kaznodziejskim funkcjonowały co najmniej 23 studia generalne, z czego 16 powstało $\mathrm{w}$ XIV wieku ${ }^{77}$. Źródła poświadczają istnienie tego typu szkół w 14 z 15 prowincji, które zostały do tego zobowiązane w konstytucji z 1304 roku. Po dwie lub trzy szkoły wyższe posiadało aż 7 prowincji: angielska, hiszpańska, dolnolombardzka, górnolombardzka, saksońska, prowansalska i tuluska. Wśród czterech prowincji, tj. polskiej, czeskiej, węgierskiej i hiszpańskiej, które zostały wymienione w projekcie uchwały z 1316 roku, trzy ostatnie już w pierwszej połowie XIV wieku otworzyły własne studia generalne. W aktach kapituł generalnych z 30. i 40. lat wspomniano aż trzy szkoły należące do prowincji hiszpańskiej. W 1350 roku do węgierskiego studium w Budzie władze zakonu skierowały lektora z prowincji czeskiej ${ }^{78}$. Od 1347 roku kapituły kilkukrotnie wysyłały studentów i lektorów do praskiego studium generalnego. Ten ostatni ośrodek jest o tyle ważny, że jako jedyny spośród wszystkich powstałych w XIV wieku studiów generalnych został „otwarty” na mocy specjalnej uchwały kapituły generalnej ${ }^{79}$. Brak natomiast podobnych uchwał dla szkół działających np. sw Cambridge, Wenecji, Mediolanie, Magdeburgu, Awinionie, Salamance, Bordeaux i Erfurcie. Przypadek praski należy więc interpretować nie tyle jako początek działania tego studium, ile raczej jako "uroczyste potwierdzenie" i dowód uznania dla osoby protektora czeskich dominikanów - króla Karola IV ${ }^{80}$. Po drugie, w wykazie 23 studiów generalnych wspomniane zostały także dwie szkoły wyższe, które ani razu nie

$77 \mathrm{~W}$ aktach kapituły generalnej z 1378 roku pojawia się również informacja o studium generalnym w miejscowości „Viceria” (MOPH, T. 4, s. 448). Dotychczas nie udało się zidentyfikować tego klasztoru (dyskusję przedstawił G. P. Hunčaga, Historické štúdie k dejinám dominikánov. Bratislava 2008, s. 73-74, przyp. 20; tenże, Dominikáni na ceste k intelektuálnym elitám vercholného stredoveku. Kraków-Bratislava 2013, s. 172-173, przyp. 394). Przypuszczam, że „Viceria” może być zepsutą formą nazwy „Venecia”, czyli Wenecja, w której - jak wiadomo - mieściło się również studium generalne.

${ }^{78}$ András Harsányi, monografista prowincji węgierskiej, błędnie zinterpretował zapis z akt kapituły generalnej z 1350 roku i stwierdził, że chodziło o przeniesienie studentów węgierskich do Budy; zob. A. Harsányi, A Domonkosrend Magyarországon a reformáció előtt. Debrecen 1938, s. 146. Dziękuję o. dr. Józefowi Puciłowskiemu OP za pomoc w lekturze tej książki.

79 Zob. MOPH, T. 4, S. 319-320: „Denunciamus fratribus universis, quod nos ad peticionem serenissimi principis et magnifici Caroli regis Romanorum illustris assignamus et ponimus studium generale in conventu Pragensi de provincia Bohemie; dicto autem conventui Pragensi lectorem assignamus fratrem Iohannem de Tambaco, magistrum in theologia in provincia Teutonie".

${ }^{80}$ Zob. J. Kłoczowski, Zakon dominikański i początki wyższego szkolnictwa na ziemiach polskich. W: Dominikanie..., s. 78. 
pojawiają się w XIV-wiecznych aktach kapituł generalnych - studium w Genui i Erfurcie. Genueńskie studium generalne bardzo szybko zyskało renomę w zakonie, czego świadectwem są asygnaty studentów z prowincji aragońskiej, niemieckiej i rzymskiej z lat 1307-1317 ${ }^{81}$. Szkoła w Erfurcie powstała najprawdopodobniej w czasie schizmy zachodniej, na początku lat $90 .{ }^{82}$. W tym miejscu warto zwrócić uwagę również na przypadek powstałego drugiej połowie XIV wieku studium generalnego $\mathrm{w}$ Rimini ${ }^{8_{3}}$. W aktach kapituł generalnych studium to zostało wspomniane tylko raz - pod rokiem 1397 - w części poświęconej asygnatom do studiów generalnych władze zakonu poinformowały o przeniesieniu studium generale z Rimini do innego konwentu prowincji dolnolombardzkiej w Padwie ${ }^{84}$. Po trzecie, analiza XIV-wiecznych asygnat do studiów generalnych pokazuje, że wystawianie tego rodzaju skierowań przez kapitułę generalną było praktyką stosunkowo rzadką. Jedynie w przypadku Paryża i Bolonii, czyli dwóch najstarszych i najważniejszych studiów generalnych, można mówić o pewnej regularności. Po czwarte, pojawienie się asygnaty do jakiegoś innego ośrodka nie dowodzi, że dopiero wówczas rozpoczął on funkcjonowanie. Dobrym przykładem są studia generalne w Oksfordzie i Cambridge, do których pierwsze asygnaty zostały wystawione przez kapitułę generalną dopiero w 1370 roku. Natomiast skierowania do powstałych jeszcze w XIII wieku studiów w Kolonii, Montpellier oraz Florencji zachowały się w aktach z 40. lat XIV wieku. Wreszcie, piąty wniosek, jaki da się wyciągnąć $\mathrm{z}$ analizy powyższego zestawienia, dotyczy bezpośrednio tematu niniejszego studium - brak w tekstach prawnych zakonu jakichkolwiek informacji na temat działalności studium generalnego w prowincji polskiej. Czy jednak powyższy wniosek jest równoznaczny z powszechnie przyjmowanym w najnowszej literaturze przedmiotu poglądem, że w XIV wieku w ogóle nie powstało krakowskie studium generalne?

${ }^{81}$ Zob. T. Kaepelli, Ein Fragment des in Friesach 1315 gefeierten Kapitels der Provinz Teutonia. „Archivum Fratrum Praedicatorum” T. 48: 1978, s. 72; Acta Capitulorum Provincialium Provinciae Romanae (1243-1344). Ed. T. Kaepelli. Romae 1941, s. 204. R. Voste, Dominicans, Muslims and Jews in the Medieval Crown of Aragon, Cambridge 2010, s. 266.

${ }^{82}$ Zob. G. M. Löhr, Die Dominikaner an den Universitäten Erfurt und Mainz. „Archivum Fratrum Praedicatorum" T. 23: 1953, s. 236-237.

${ }_{8}^{8}$ Zob. G. C. Mengozzi, I domenicani a Rimini. „Memorie Domenicane” T. 46: 1929, s. 192-337; R. Parmeggiani, Ordini mendicanti nella città e nella diocesi. W: Storia della Chiesa riminese. T. 2. Pod red. A. Vasina. Rimini 2011, s. 287-288.

${ }^{84}$ Zob. MOPH, T. 8, s. 98: „Removemus studium generale theologie de conventu Aryminensi de provincia s. Dominici et assignamus in conventum Paduanam eiusdem provincie”. 


\section{III}

W świetle przedstawionych w niniejszym studium obserwacji i uwag odpowiedź na to ostatnie pytanie może być jedynie przecząca. Wiadomo bowiem, że decyzja władz zakonu o powstaniu w 15 prowincjach, w tym także w Polsce, szkół wyższych nie była pochopna, ale poprzedzała ją wieloaspektowa ocena sytuacji wewnętrznej danej jednostki zakonu. $\mathrm{Z}$ tych powodów prowincja $\mathrm{Da}$ cji, pomimo odpowiednich warunków materialnych i kadrowych, nie została uwzględniona w tekście uchwały. W dalszych latach kapituły ewidentnie wspierały i kontrolowały prace nad organizacją nowych studiów - bądź to poprzez odpowiednie dyspensy (1305) bądź groźby (1316). Nigdy jednak - co trzeba podkreślić - decyzja z 1304 roku nie została ani odwołana, ani zawieszona. Ewidentnie władze zakonu zostawiały studiom generalnym dużą swobodę działania, w tym również przy obsadzie stanowisk profesorskich. Odnaleźć można zaledwie kilka asygnat do tak prestiżowych szkół jak w Oksfordzie, Cambridge, Mediolanie, Bordeaux czy też w Wenecji, a żadnego do studium w Rimini, a później w Padwie. Niekiedy mogło się też zdarzyć, że pewne studia, jak np. w Genui i Erfurcie, nigdy nie znalazły się w centrum zainteresowania kapituł generalnych. Widać zatem wyraźnie, że na podstawie analizy akt kapituł generalnych nie sposób przekonująco uzasadnić tezy o nieistnieniu w XIV-wiecznej polskiej prowincji studium generalnego.

W dotychczasowej dyskusji nad początkami krakowskiego studium generalnego badacze zwracali uwagę na brak w XIV wieku odpowiednich warunków na poziomie szkolnictwa zakonnego oraz sprzyjających okoliczności, które umożliwiałyby polskim braciom realizację konstytucji z 1304 roku. Zdaniem Jerzego Kłoczowskiego XIV-wieczny polski system edukacji dominikańskiej był „zapewne słabszy, mniej rozwinięty niż w prowincjach przodujących i o wiele bogatszy-

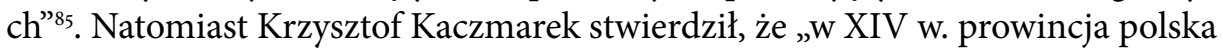
odstawała od zachodnich okręgów Zakonu w zakresie organizowania struktur szkolnictwa partykularnego”, a „liczebność szkół partykularnych na terenie polskiej prowincji była bez wątpienia mniejsza niż w analogicznych ośrodkach na zachodzie Europy" ${ }^{86}$. Problemy szkolnictwa byłyby zatem - w opinii tych badaczy - rezultatem i wyraźnym świadectwem trudności, jakie przeżywała polska prowincja dominikanów w XIV wieku. Trzeba jednak powiedzieć, że

\footnotetext{
${ }^{85}$ J. Kłoczowski, Zakon dominikański..., s. 76.

${ }^{86}$ K. Kaczmarek, Szkoły i studia..., s. 306, 308.
} 
ta - dość pesymistyczna - interpretacja historii miejscowych braci nie znajduje potwierdzenia w materiale źródłowym.

W ostatnich latach udało się odnaleźć i opracować szereg nowych źródeł do XIV-wiecznych dziejów polskich dominikanów. Prawdziwy przełom w badaniach przyniosło odkrycie w monachijskiej Bayerische Staatsbibliothek fragmentów akt dwóch kapituł prowincjalnych dominikanów polskich z $1384^{87}$ i 1395 lub 1397 roku $^{88}$. Analiza tekstu obu pozwoliła sformułować kilka ważnych z perspektywy niniejszego studium wniosków. Warto przytoczyć dwa z nich: „Dominikanie polscy posiadali co najmniej 26 szkół partykularnych: 8 - studia artium, 8 - studia naturarum, 9 - studia theologiae. W tym samym okresie w prowincji hiszpańskiej działało 29 tego typu szkól, a w prowincji saskiej - 22. W świetle tych danych możemy przekonująco podważyć mocno już ugruntowany w literaturze pogląd na temat rzekomej słabości polskiego systemu edukacji. Trzeba zatem jednoznacznie stwierdzić, że szkolnictwo partykularne dominikanów polskich w XIV w. w zakresie organizacji nie było ani mniej rozwinięte, ani też nie odstawało od zachodnich okręgów Zakonu"s9. „Polscy dominikanie byli mocno zainteresowani poziomem życia intelektualnego $\mathrm{w}$ swojej prowincji [...]. Ogłoszenie przez kapitułę tych ordinationes potwierdza tezę, że już w 9o. latach XIV w. polska prowincja dominikanów posiadała nie tylko dobrze rozwiniętą organizację szkolnictwa, ale również świadome swojej pozycji i wpływów środowisko wykładowców. Niewątpliwie zatem istniały odpowiednie i wystarczające warunki pod fundację studium generalnego, co też nastąpiło - jak się obecnie przyjmuje - na początku XV stulecia" ${ }^{\circ}$. Okazuje się jednak, że rozwojem życia umysłowego zainteresowani byli nie tylko bracia w ostatniej ćwierci XIV wieku, ale również wcześniejsze pokolenia zakonników. Analiza zachowanego księgozbioru dominikanów krakowskich oraz odnalezienie w Bibliotece Jagiellońskiej „rewersu bibliotecznego" prowincjała Macieja z lat 30. wieku XIV pozwoliły stwierdzić, że krakowscy zakonnicy już w pierwszej połowie tego stulecia studiowali tę samą literaturę teologiczną co ich konfratrzy z innych ośrodków w Europie Zachodniej oraz

${ }^{87}$ Zob. T. Gałuszka, Fragmenty czternastowiecznych akt..., s. 107-122 (edycja tekstu: s. 118122); tenże, Szkolnictwo konwentualne i partykularne w strukturach polskiej prowincji dominikanów XIV stulecia. Nowe ujęcie w świetle nowych źródeł. „Roczniki Historyczne” T. 78: 2012, s. 191-211.

${ }^{88}$ Zob. tenże, Fragment akt..., s. 119-145 (edycja tekstu: s. 140-144).

${ }^{89}$ Tenże, Szkolnictwo..., s. 210.

90 Tenże, Fragment akt..., 139. 
orientowali się $\mathrm{w}$ toczonych wewnątrz zakonu debatach tomistycznych ${ }^{91}$. Co więcej, polscy dominikanie znali i promowali najnowsze, a nieraz i kontrowersyjne koncepcje teologiczne. Dobrym przykładem może być postać brata Mikołaja Duthorowa OP, który w 30. latach XIV wieku wprowadzał do swojego kaznodziejstwa wątki teologiczne dwóch sobie współczesnych dominikanów niemieckich: Eckharta $z$ Hochheim i Henryka Suzona ${ }^{92}$. Nie ulega zatem wątpliwości, że polscy dominikanie nie odbiegali poziomem życia umysłowego i stopniem organizacji szkolnictwa od swoich współbraci z innych prowincji, które posiadały własne studia generalne.

Pozostając przy problematyce szkolnej, warto wspomnieć jeszcze o jednym zagadnieniu, wprowadzonym do dyskusji nad początkami krakowskiego studium generalnego przez Pawła Kielara OP. Dominikanin ten uznał, że pojawienie się wśród polskich braci mistrza teologii było równoznaczne z objęciem przez niego funkcji regensa, czyli głównego wykładowcy w studium generalnym. Zdaniem Kielara pierwszym regensem krakowskiej szkoły miał zostać w 1394 roku Franciszek Oczko, określony w źródłach mianem lector summus ${ }^{93}$. Krzysztof Kaczmarek ${ }^{94}$ oraz Maciej Zdanek ${ }^{95}$ przedstawili szereg argumentów, które osłabiły propozycję tego badacza. Zwrócili oni uwagę, że Franciszek nie był pierwszym mistrzem teologii pochodzącym z polskiej prowincji dominikanów; obecność mistrza teologii nie świadczy o istnieniu studium generalnego; tytuł lector summus $\mathrm{w}$ ogóle nie występuje $\mathrm{w}$ dominikańskich źródłach normatywnych. Kaczmarek zapytał wprost: „Dlaczego więc tylko w odniesieniu do Franciszka Oczki używano mało popularnego określenia lector summus, a nie bardziej rozpowszechnionego tytułu regens studium?"96. Niewątpliwie łączenie osoby Franciszka Oczki z momentem powstania studium generalnego w Krakowie jest przedsięwzięciem karkołomnym. Trzeba jednak zauważyć, że zgłoszone zarzuty nie podważają ani hipotezy istnienia tego studium w XIV wieku, ani też możliwości, że Franciszek rzeczywiście stał na czele tej szkoły

${ }^{91}$ Tenże, $W$ przededniu powstania..., s. 25-42 (edycja tekstu: s. 28).

${ }_{22}$ Zob. tenże, Mikołaja Duthorowa OP „error condemnatus ab Ecclesia”. Dominikanie polscy wobec herezji i nowych nurtów pobożności w 1. połowie XIV wieku. „Kwartalnik Historyczny” T. 122: 2014, nr 1, s. 73-106.

${ }_{93}$ P. Kielar, Studia nad kultura..., s. 345. Zob. Biblioteka Uniwersytecka we Wrocławiu, rkps IV F 198, k. 15; sygn. I Q 451.

${ }^{94}$ Zob. K. Kaczmarek, Głos w dyskusji..., s. 87-99; tenże, Szkoły i studia..., s. 334-335.

${ }^{95}$ Zob. M. Zdanek, Szkoty i studia..., s. 106-107.

${ }_{96}^{6}$ Zob. K. Kaczmarek, Głos w dyskusji..., s. 92. 
wyższej. Fakt określenia tego dominikanina tytułem lector summus zamiast regens studium można bowiem dość łatwo wyjaśnić. W XIII- i XIV-wiecznych aktach kapituł generalnych na określenie głównego wykładowcy zarówno w studium generalnym, jak i studium partykularnym - a niekiedy też w szkole konwentualnej - używano przeważnie jednego tytułu: lector principalis lub po prostu lector ${ }^{97}$. W XIV stuleciu na kilkadziesiąt asygnat do studiów generalnych pojawiają się zaledwie 4 asygnaty pro regente ${ }^{98}$. Zasadnicza zmiana zarysowała się dopiero w pierwszym dziesięcioleciu XV wieku i wówczas władze zakonu powszechnie zaczęły stosować tytuł regensa dla zwierzchnika szkoły wyższej99. Stąd też poszukiwanie w XIV-wiecznych źródłach dominikanów z tytułem regens studium może okazać się zadaniem trudnym do wykonania. $Z$ kolei oryginalne określenie lector summus jest niewątpliwie rzadkim, ale spotykanym synonimem tytułu lector principalis. W ten sposób został nazwany w 1350 roku przeor i główny wykładowca w dominikańskim studium teologii w Maastricht ${ }^{100}$. Zapewne również Franciszek Oczko stał na czele jakiejś szkoły, nie wiadomo jednak, czy było to studium generalne, czy też partykularne.

Oczywiście szkolnictwo jest tylko jednym z elementów życia zakonnego. Jednak analiza także innych aspektów historii polskich dominikanów nie daje żadnych podstaw, aby mówić o słabości miejscowej prowincji w XIV stuleciu. W tym miejscu warto przypomnieć kilka najważniejszych faktów. W pierwszej połowie XIV wieku, a zatem w czasie gdy powstawało większość nowych studiów generalnych, polscy dominikanie - zwłaszcza z klasztoru krakowskiego - prężnie rozwijali swoją działalność oraz wypracowywali mocną pozycję w lokalnym Kościele. Znane są świadectwa bliskich relacji i współpracy m.in. $\mathrm{z}$ arcybiskupem Janisławem ${ }^{101}$ oraz biskupami diecezjalnymi Nankerem i Janem Grotowicem $^{102}$. Wraz z powstaniem w 1327 roku inkwizycji papieskiej w Polsce

${ }_{97}$ Zob. M. Zdanek, Szkoły i studia..., s. 107; tenże, Regensi..., s. 80-81.

${ }_{98}^{8}$ Zob. MOPH, T. 4, s. 417, 447, 448; T. 8, s. 9.

99 Zob. M. Zdanek, Regensi..., s. 81-82

${ }^{100}$ Zob. G. D. Franquinet, Histoire des couvents de l'ordre de St. Dominique dans le Limbourg. Maestricht 1854, s. 17-18.

${ }^{101}$ Zob. tenże, Dominikanie $i$ spory wokót prawa do stuchania spowiedzi. Recepcja bulli Jana XXII „Vas electionis” $w$ diecezji wrocławskiej w1. połowie XIV wieku. „Studia Źródłoznawcze” T. 52: 2014, s. 3-22.

${ }^{102}$ Zob. tenże, Kolektor Piotr $z$ Auvergne i plebani versus biskup Jan Grotowic i dominikanie. $Z$ badań nad polskimi dominikanami i dziejami diecezji krakowskiej w 1. połowie XIV wieku. „Przegląd Historyczny" T. 105: 2014, nr 3, s. 315-337. 
bracia dość gorliwie przyjęli rolę „obrońców i strażników” ortodoksyjnego nauczania Kościoła. Znamiennym przykładem tego zaangażowania jest choćby antyheretycki traktat Contra beghardos autorstwa czeskiego dominikanina Henryka Harrera. Dzieło to powstało na specjalne zlecenie jego polskich współbraci jako reakcja na pojawienie się w diecezji krakowskiej pewnej grupy osób, których sposób życia i praktyki religijne były odmienne od zachowań pozostałych wiernych ${ }^{103}$. Prawdziwym wskaźnikiem żywotności i kondycji danej wspólnoty zakonnej jest aktywność ad intra, czyli zakładanie nowych fundacji klasztornych, oraz ad extra, czyli działalność misyjna. W XIV wieku powstało 8 klasztorów, z czego aż 6 w 3o. latach tego wieku: Krosno Odrzańskie (ok. 1330), Żmigród (1331), Sandomierz, konwent św. Marii Magdaleny (1334), Ińsko (1334), Brzeg (ok. 1335 r.), Żnin (1336), Piotrków (ok. 1370), Bochnia (ok. 1370). W połowie XIV wieku daje się zauważyć również wzmożona aktywność misyjna dominikanów polskich na Rusi Czerwonej ${ }^{104}$. Wówczas to we Lwowie został ufundowany pierwszy w XIV wieku dominikański klasztor na ziemiach ruskich ${ }^{105}$. Niedługo później powstały kolejne domy, m.in. w Przemyślu, Łańcucie, Kamieńcu Podolskim i Smotryczu ${ }^{106}$. Polscy dominikanie weszli także w skład powołanej przez papieża na początku XIV wieku organizacji misyjnej

${ }^{103}$ Zob. tenże, Krakowscy pobożni laicy czy begardzi heretycy? Z badań nad czternastowiecznym „Tractatus contra begharodos” Henryka Harrera. „Folia Historica Cracoviensia” Vol. 18: 2012, s. 47-73; tenże, Kryzys w diecezji krakowskiej w pierwszej połowie XIV wieku? Z badań nad „Tractatus contra beghardos" Henryka Harrera. W: Ecclesia semper reformanda. Kryzysy i reformy średniowiecznego Kościoła. Pod red. T. Gałuszki, T. Graffa, G. Rysia. Kraków 2013, s. 285-300.

${ }^{104}$ Tenże, Versus Russiam. Dominikanie polscy wobec polityki misyjnej papieża Jana XXII [w przygotowaniu].

${ }^{105}$ Zob. T. M. Trajdos, Dominikanie na ziemiach ruskich państwa polsko-litewskiego $w$ średniowieczu. W: Dzieje dominikanów w Polsce XIII-XVIII wiek. Pod red. H. Gapskiego, J. Kłoczowskiego, J. A. Spieża. Lublin 2006, s. 146-166 (tutaj wcześniejsza bibliografia nt. klasztoru lwowskiego); tenże, Kaznodzieje dominikańscy we Lwowie w XV wieku. W: Kaznodziejstwo średniowieczne - Polska na tle Europy. Teksty, atrybucje, audytorium. Pod red. K. Brachy. Warszawa 2014, s. 141-154; K. Kaczmarek, Jeszcze o lektorach i studentach $w$ średniowiecznej prowincji polskich dominikanów oraz ich szkołach w Krakowie i we Lwowie. „Nasza Przeszłość” T. 88: 1997, s. 59-89.

${ }^{106}$ Zob. J. T. Frazik, Przemiany przestrzenne kościoła Dominikanów w Łańcucie. „Teka Komisji Urbanistyki i Architektury" T. 4: 1970, s. 181-197; J. A. Spież, Dominikanie w Kamieńcu Podolskim. W: Pasterz i twierdza. Pod red. J. Wołczańskiego. Kraków-Kamieniec Podolski 2001, s. 249-273; W. Koszewierski, Dominikanie klasztorów ruskich. Lublin 2006, s. 53-63 (rec. K. Kaczmarka, „Nasza Przeszłość” T. 109: 2008, s. 339-351); W. Zawitkowska, Święty Jacek Odrowąż i jego związki $z$ Przemyślem. W: Święty Jacek Odrowąż i dominikanie na Śląsku. Pod red. A. Barciaka. Katowice 2008, s. 56-75. 
prowadzonej przez Kongregację Braci Pielgrzymujących ${ }^{107}$. Dominik Polak przebywał w 1333 roku w stacji misyjnej w Azowie nad Donem, gdzie oprócz pracy duszpasterskiej pełnił funkcję tłumacza z języka kipczackiego na język łaciński ${ }^{108}$. Kiedy $\mathrm{w}$ drugiej połowie XIV wieku klasztory ruskie utworzyły własny wikariat $\mathrm{w}$ ramach Kongregacji Braci Pielgrzymujących, tamtejsi dominikanie - zgodnie $\mathrm{z}$ decyzją kapituł generalnych - podlegali polskiemu prowincjałowi ${ }^{109}$. Polskie władze czuły się odpowiedzialne za rozwój tego dzieła misyjnego, czego najlepszym dowodem jest jedno z zarządzeń, znajdujące się w odnalezionych w Monachium aktach kapituły prowincjalnej - kapituła zachęcała wszystkich braci do udzielenia wszelkiej pomocy i wsparcia dominikanom de Societate ${ }^{110}$. Z pewnością otwarcie polskiej prowincji w XIV wieku na misje wschodnie - wbrew niektórym głosom ${ }^{111}$ - nie mogło przeszkodzić w założeniu i prowadzeniu własnej szkoły wyższej. W końcu należy wspomnieć o kryzysie życia zakonnego, jaki dotknął w XIV wieku cały zakon domini-

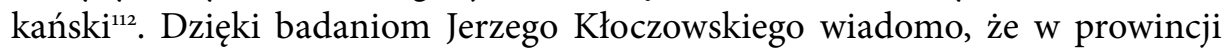
polskiej nie doszło do wytworzenia się konwentualizmu w najjaskrawszych formach ${ }^{113}$. Akta polskich kapituł $\mathrm{z}$ lat 80 . i 9o. tego wieku pokazują, że władze prowincji zdecydowanie reagowały na jakiekolwiek przejawy osłabienia karności zakonnej ${ }^{114}$. Trzeba jednak podkreślić, że sam fakt pojawienia się tych postanowień ani nie musi wskazywać na jakiś szczególny upadek życia polskich dominikanów pod koniec XIV wieku, ani też przeciwnie - dowodzić przyłączenia się do dzieła reformy obserwanckiej, zainicjowanej przez generała Rajmunda z Capui.

Powyższy szkic obrazu polskiej prowincji dominikanów w XIV wieku - zarówno w kontekście polityki szkolnej, fundacyjnej, misyjnej, jak i relacji z lokalnym środowiskiem kościelnym - można potraktować jako weryfikację

${ }_{107}$ Zob. przyp. 44 .

${ }^{108}$ Dominik Polak był autorem tłumaczenia traktatu handlowego między chanem Złotej Orty Uzbekiem i kupcami weneckimi, R. Loenertz, La Société..., s. 97, 102.

${ }^{109}$ Zob. M. Zdanek, Szkoły i studia..., s. 96-97.

${ }_{110}$ Zob. T. Gałuszka, Fragment akt..., s. 141.

${ }^{111}$ Zob. K. Kaczmarek, Głos w dyskusji..., s. 97.

${ }^{112}$ Zob. W. A. Hinnebusch, Dominikanie - krótki zarys dziejów. W: Dominikanie. Szkice z dziejów zakonu. Pod red. M. A. Babraja. Poznań 1986, s. 159-162; M. Vargas, Taming a brood of vipers. Conflict and change in fourteenth-century Dominican convents. Boston 2011.

${ }_{113}$ Zob. J. Kłoczowski, Dominikanie polscy..., s. 163.

${ }_{114}$ Zob. T. Gałuszka, Fragment akt..., s. 139. 
twierdzenia o rzekomym braku odpowiednich warunków w tej części zakonu do założenia studium generalnego. Czy zatem już w tym właśnie stuleciu mogła w Krakowie powstać dominikańska szkoła wyższa? Podsumowując wszystkie ustalenia, chciałbym zaproponować lub raczej powtórnie wprowadzić do dyskusji naukowej zarzuconą hipotezę: prawdopodobnie studium generalne polskich dominikanów powstało już w XIV wieku, być może niedługo po ogłoszeniu w 1304 roku zmian w rozdziale De studentibus. Mogę tylko wyrazić nadzieję, że odkrycie nowych źródeł pozwoli w niedalekiej przyszłości na definitywne rozstrzygnięcie tej kwestii.

\section{Streszczenie}

\section{Studium generalne dominikanów polskich w XIV wieku?}

Głównym tematem artykułu jest geneza studium generalnego dominikanów polskich. W wyniku wieloletnich i skomplikowanych badań prowadzonych przez Krzysztofa Kaczmarka i Macieja Zdanka udało się ustalić, że pierwsze źródłowe dowody potwierdzające funkcjonowanie krakowskiego studium generale pochodzą z lat 1404/1405-1410. Jednak przytoczone daty stanowią jedynie terminus ante quem powstania tego ośrodka kształcenia. Autor skupił się na pewnym wydarzeniu z lat 1304-1316, które w literaturze przedmiotu nazywane jest zazwyczaj „nieudaną próbą utworzenia studium generalnego w Krakowie". Ponowna analiza dominikańskich akt kapituł generalnych, sytuacji wewnętrznej zakonu w pierwszej połowie XIV wieku oraz dziejów polskiej prowincji dominikanów pozwoliły zaproponować lub raczej powtórnie wprowadzić do dyskusji naukowej zarzuconą dawną hipotezę: prawdopodobnie studium generalne polskich dominikanów powstało już w XIV wieku, być może niedługo po ogłoszeniu w 1304 roku zmian w rozdziale De studentibus.

\section{Słowa kluczowe}

studium generalne dominikanów, szkolnictwo zakonne, Polska Prowincja Dominikanów w XIV wieku, Kościół w XIV wieku, kapituły generalne dominikanów 


\section{Summary}

\section{A general study of Polish Dominicans in the 14th century?}

The main topic of the article is the founding of a general study of the Polish Dominicans. The lengthy and complex research conducted by Krzysztof Kaczmarek and Maciej Zdanek established that the first source-based evidence confirming the activity of Krakow's studium generale comes from 1404/1405-1410. However, the above dates are just terminus ante quem of the origins of this educational centre. The author focused on an event from 1304-1316, which professional literature on the subject tends to describe as 'an unsuccesful attempt to create a general study in Krakow'. A new analysis of the Dominican chapter house documents, the internal dynamic of the order in the early 14th century, as well as the history of the Polish Dominican province, allowed to put forth or re-introduce a previously-abandoned hypothesis into the academic discussion; the hypothesis suggests that, most likely, the general study of the Polish Dominicans was founded in the 14th century already, perhaps soon after the 1304 announcement of changes in the chapter De studentibus.

\section{Keywords}

general study of Dominicans, Dominican education, Polish Dominican province in the 13th c., Krakow Church in the 14th c., general charter of Dominicans

\section{Bibliografia}

\section{Źródła rękopiśmienne}

Biblioteka Uniwersytecka we Wrocławiu, rkps IV F 198.

Biblioteka Uniwersytecka we Wrocławiu, rkps I Q 451.

\section{Źródła drukowane}

Acta capitulorum generalium ordinis Praedicatorum. Ed. B. M. Reichert. W: Monumenta

Ordinis Fratrum Praedicatorum historica. T. 1-8. Romae-Stuttgardiae 1898-1899.

Acta capitulorum Provincialium Provincice Romanice (1243-1344). Ed. T. Kæppeli.

Romæ 1941.

\section{Opracowania}

Creytens R., Les constitutions des frères prêcheurs dans la redaction de s. Raymond de Peñafort (1241). „Archivum Fratrum Praedicatorum” T. 18: 1948, s. 5-68. 
Delacroix-Besnier C., Les Dominicains et la chrétienté grecque aux XIV et XVe siècles. Rome 1997.

Emden A. B., Dominican confessors and preachers. „Archivum Fratrum Praedicatorum” T. 32: 1962, s. 180-210.

Emden A. B., A survey of Dominicans in England based on the ordination lists in episcopal registers (1268 to 1538). Rome 1967.

Franquinet G. D., Histoire des couvents de l'ordre de St. Dominique dans le Limbourg. Maestricht 1854.

Frazik J. T., Przemiany przestrzenne kościoła Dominikanów w Łańcucie. „Teka Komisji Urbanistyki i Architektury” T. 4: 1970, s. 181-197.

Gallén J., La province de Dacie de l'Order des Frères Prêcheurs. Helsingfors 1946.

Gałuszka T., W przededniu powstania „studium generale”. Nowe badania nad czternastowiecznym zachowanym księgozbiorem dominikanów krakowskich, „Przegląd Tomistyczny" T. 16: 2010, s. 25-42.

Gałuszka T., Fragmenty czternastowiecznych akt kapitut prowincjalnych dominikanów polskich $w$ zbiorach Bayerische Staatsbibliothek $w$ Monachium. Kapituła prowincjalna w Opatowcu w 1384 r. „Studia Źródłoznawcze” T. 51: 2013, s. 105-120.

Gałuszka T., Liber constitutionum dominikanów krakowskich z lat 1273-1318. „Studia Źródłoznawcze" T. 50: 2012, s. 1-25.

Gałuszka T., Fragment akt kapituły prowincjalnej dominikanów polskich z 9o. lat XIV wieku. Studium historyczne i edycja tekstu. „Roczniki Historyczne” T. 79: 2013, s. 119-146.

Gałuszka T., Szkolnictwo konwentualne i partykularne w strukturach polskiej prowincji dominikanów XIV stulecia. Nowe ujęcie w świetle nowych źródeł. „Roczniki Historyczne" T. 78: 2012, s. 191-211.

Gałuszka T., Mikołaja Duthorowa OP „error condemnatus ab Ecclesia”. Dominikanie polscy wobec herezji i nowych nurtów pobożności w 1. połowie XIV wieku. „Kwartalnik Historyczny" T. 122: 2014, nr 1, s. 73-106.

Gałuszka T., Dominikanie i spory wokó prawa do słuchania spowiedzi. Recepcja bulli Jana XXII „Vas electionis” w diecezji wrocławskiej w 1. połowie XIV wieku. „Studia Źródłoznawcze" T. 52: 2014, s. 3-22.

Gałuszka T., Kolektor Piotr $z$ Auvergne i plebani versus biskup Jan Grotowic i dominikanie. $Z$ badań nad polskimi dominikanami i dziejami diecezji krakowskiej w 1. połowie XIV wieku. „Przegląd Historyczny” T. 105: 2014, nr 3, s. 315-337.

Gałuszka T., Krakowscy pobożni laicy czy begardzi heretycy? Z badań nad czternastowiecznym „Tractatus contra begharodos” Henryka Harrera. „Folia Historica Cracoviensia" Vol. 18: 2012, s. 47-73.

Gałuszka T., Kryzys w diecezji krakowskiej w pierwszej połowie XIV wieku? Z badań nad „Tractatus contra beghardos” Henryka Harrera. W: Ecclesia semper reformanda. Kryzysy i reformy średniowiecznego Kościoła. Pod red. T. Gałuszki, T. Graffa, G. Rysia. Kraków 2013, s. 285-300.

Galbraith G. R., The constitution of the Dominican order 1216 to 1360 . Manchester 1925.

Hinnebusch W. A., The history of the Dominican order. Vol. 2. New York 1973. 
Hinnebusch W. A., Dominikanie - krótki zarys dziejów. W: Dominikanie. Szkice z dziejów zakonu. Pod red. M. A. Babraja. Poznań 1986, s. 159-162.

Hommedal A. T., The medieval Dominican friary of St Olav in Oslo, Norway: history and architecture. W: Dominikanie. Gdańsk - Polska - Europa. Pod red. D. A. Dekańskiego, A. Golembnika, M. Grubki. Gdańsk-Pelplin 2003, s. 371-388.

Harsányi A., A Domonkosrend Magyarországon a reformáció elött. Debrecen 1938.

Hunčaga G. P., Historické štúdie k dejinám dominikánov. Bratislava 2008.

Hunčaga G. P., Dominikáni na ceste k intelektuálnym elitám vercholného stredoveku. Kraków-Bratislava 2013.

Kaczmarek K., Wokół historiograficznych sporów o początki dominikańskiego studium generalnego w Krakowie. „Przegląd Tomistyczny” T. 16: 2010, s. 13-24.

Kaczmarek K., Szkoły i studia polskich dominikanów w okresie średniowiecza. Poznań 2005.

Kaczmarek K., Podział polskiej prowincji dominikanów na przełomie XIII i XIV w. W: Kościół w monarchiach Przemyslidów i Piastów. Poznań 2009, s. 259-274. Materiały z konferencji naukowej Gniezno 21-24 września 2006 roku. Pod red. J. Dobosza.

Kaczmarek K., Głos w dyskusji nad początkami studium generalnego dominikanów w Krakowie. „Nasza Przeszłość” T. 91: 1999, s. 77-100.

Kaczmarek K., Jeszcze o lektorach $i$ studentach $w$ średniowiecznej prowincji polskich dominikanów oraz ich szkołach w Krakowie i we Lwowie. „Nasza Przeszłość” T. 88: 1997, s. 59-89.

Kaepelli T., Ein Fragment des in Friesach 1315 gefeierten Kapitels der Provinz Teutonia. „Archivum Fratrum Praedicatorum” T. 48: 1978, s. 71-75.

Kielar P., Studia nad kulturą szkolna i intelektualną dominikanów prowincji polskiej w średniowieczu. W: Studia nad historia dominikanów w Polsce 1222-1972. Pod red. J. Kłoczowskiego. T. 1. Warszawa 1975, s. 271-515.

Kłoczowski J., Dominikanie polscy na Ślasku w XIII-XIV wieku. Lublin 1956.

Kłoczowski J., Zakon dominikański i początki wyższego szkolnictwa na ziemiach polskich. W: Dominikanie. Gdańsk - Polska - Europa. Pod red. D. A. Dekańskiego, A. Golembnika, M. Grubki. Gdańsk-Pelplin 2003, s. 67-87.

Korolec J. K., Studium Generalne w Krakowie - prawne warunki istnienia. „Materiały i Studia Zakładu Historii Filozofii Starożytnej i Średniowiecznej” T. 4: 1965, s. 101-126.

Korolec J. K., Studium generale dominikanów klasztoru Świętej Trójcy w Krakowie. W: Dominikanie w środkowej Europie w XIII-XV wieku. Pod red. J. Kłoczowskiego, J. A. Spieża. Poznań 2002, s. s. 173-186.

Koszewierski W., Dominikanie klasztorów ruskich. Lublin 2006.

Loenertz R., La Société des Fréres Pérégrinants, Roma 1937.

Löhr G. M., Die Kölner Dominikanerschule vom 14. bis zum 16. Jahrhundert mit einer Übersicht über die Gesamtentwicklung. Köln 1948.

Löhr G. M., Die Dominikaner an den Universitäten Erfurt und Mainz. „Archivum Fratrum Praedicatorum" T. 23: 1953, s. 236-274.

Magister Raimundus. Atti del convegno per il IV centenario della canonizzazione di San Raimondo de Penyafort: 1601-2001. Pod red. C. Longo. Roma 2002. 
Mengozzi G. C., I domenicani a Rimini. „Memorie Domenicane” T. 46: 1929, s. 192-337

Mortier D. A., Histoire des Maitres Généraux. T. 2. Paris 1905.

Mulchahey M. M., "First the bow is bent in study”. Dominican education before 1350 . Toronto 1998.

Parmeggiani R., Ordini mendicanti nella città e nella diocesi. W: Storia della Chiesa riminese. T. 2. Pod red. A. Vasina. Rimini 2011, s. 287-288.

Rosenorn Lehn E. F., La province de Dacia (Danemark, Suède et Norvèqe). Rome 1899.

Sibilio V., Benedetto XI. Il papa tra Roma e Avignone. Roma 2004.

Spież J. A., Dominikanie w Kamieńcu Podolskim. W: Pasterz i twierdza. Pod red. J. Wołczańskiego. Kraków-Kamieniec Podolski 2001, s. 249-273.

Świętochowski R., Szkolnictwo teologiczne dominikanów. W: Dzieje teologii katolickiej $w$ Polsce. T. 2: Od Odrodzenia do Oświecenia, cz. 2: Teologia neoscholastyczna i jej rozwój w akademiach i szkołach zakonnych. Pod red. M. Rechowicza. Lublin 1978, s. $211-285$.

Torrell J. P., Tomasz z Akwinu - człowiek i dzieło. Przeł. A. Kuryś. Warszawa 2008.

Trajdos T. M., Dominikanie na ziemiach ruskich państwa polsko-litewskiego $w$ średniowieczu. W: Dzieje dominikanów w Polsce XIII-XVIII wieku. Pod red. H. Gapskiego, J. Kłoczowskiego, J. A. Spieża. Lublin 2006, s. 147-166.

Trajdos T. M., Kaznodzieje dominikańscy we Lwowie w XV wieku. W: Kaznodziejstwo średniowieczne - Polska na tle Europy. Teksty, atrybucje, audytorium. Pod red. K. Brachy. Warszawa 2014, s. 141-154.

Turek J., Regens krakowski Jan z soboru pizańskiego w świetle dwóch traktatów Jana Falkenberga. „Przegląd Tomistyczny” T. 16: 2010, s. 43-57.

Vargas M., Taming a brood of vipers. Conflict and change in fourteenth-century Dominican convents. Boston 2011.

Voste R., Dominicans, Muslims and Jews in the Medieval Crown of Aragon. Cambridge 2010.

Zajchowska A., Czy w dominikańskim „studium generale” w Krakowie urządzano otrzęsiny? „Collatio de beanis” w rękopisie LXV6 z Archiwum Polskiej Prowincji Dominikanów w Krakowie. „Przegląd Tomistyczny” T. 16: 2010, s. 59-75.

Zawitkowska W., Święty Jacek Odrowąż i jego związki z Przemyślem. W: Święty Jacek Odrowąż i dominikanie na Śląsku. Pod red. A. Barciaka. Katowice 2008, s. 56-75.

Zdanek M., Regensi dominikańskiego studium generalnego w Krakowie do 1596 r. „Przegląd Tomistyczny" T. 16: 2010, s. 77-124.

Zdanek M., Szkoły i studia dominikanów krakowskich w średniowieczu. Warszawa 2005. 
